\title{
Civil-military relations in peacebuilding
}

\author{
Karen Guttieri*
}

\begin{abstract}
Civil-military relations are vital to the coherence and effectiveness of post-conflict peacebuilding, but have often been problematic. This article argues that civil-military issues vary systematically in relation to the particular civil and military actors in peacebuilding, and that the coercive content of the external military's mission creates special challenges in each of these sets of relationships. Given the significance of the military footprint, the article presents trade-offs for policymakers intending to use military forces to make peace.
\end{abstract}

Key words: peacebuilding, peacekeeping, civil-military relations, coalitions, United Nations, conflict resolution

$\mathrm{I}$ $\mathrm{n}$ traditional UN peacekeeping missions deployed during the Cold War, military forces supervised and monitored cease fires between states, usually in the wake of a peace agreement and authorized under Chapter VI of the UN charter. At about the same time that the Cold War ended and great powers were more inclined to work together in the Security Council, the UN shifted focus to respond to the pressing need for a more comprehensive and sometimes coercive response to internal conflict. Peacebuilding, introduced in 1992 by UN Secretary-General Boutros Boutros-Ghali, sought not merely to keep apart conflicting factions but to build structures that would sustain peace. ${ }^{1}$ As compared to previous peacekeeping efforts, peacebuilding would require greater synergy across spheres of assistance - social, economic, humanitarian, security, and political-administrative - and among an increasing variety of agencies and actors facilitating transitions to peace. At the turn of the century, an emergent international consensus on coherence - the coordination of intervention and humanitarian actions - matured. $^{2}$ At this same moment, military interventions by the North Atlantic Treaty Organization (NATO) in Kosovo, USled coalition forces in Afghanistan, and a US- and British-led coalition in Iraq, created deep divisions about the rightfulness of intervention, the balance between civilian and military components within it, and the governance of what would follow.

Civil-military synergy is particularly vital to managing postconflict transitions, but has too often been problematic. ${ }^{3}$ Civil and military actors, both within various troop-

* Karen Guttieri is an Assistant Professor at the Naval Postgraduate School, Monterey, California, affiliated with the Center for International Security and Cooperation, Stanford University. She holds a PhD in Political Science from the University of British Columbia, Canada.

This article was prepared for the United Nations University-IFSH project »The Role of the Military in Post-Conflict Peacebuilding. « The author acknowledges the project directors Hans-Georg Ehrhart (IFSH) and Albrecht Schnabel (swisspeace), the members of the project team as well as two anonymous peer reviewers for their input in the preparation of this article.

1 Boutros-Ghali described peacebuilding as »action to identify and support structures which will tend to strengthen and solidify peace in order to avoid a relapse into conflict. "United Nations, Secretariat, An Agenda for avoid a relapse into conflict. « United Nations, Secretariat, An Agenda for
Peace: Preventive diplomacy, peacemaking and peace-keeping, Report of the SecPeace: Preventive diplomacy, peacemaking and peace-keeping, Report of the Sec-
retary-General pursuant to the statement adopted by the Summit Meeting of the
Security Council on 31 January 1992 (A/47/277 - S/24111), 17 June 1992. See also Elizabeth M. Cousens, »Introduction «, in Elizabeth Cousens and Chetan Kumar, with Karin Wermester, eds., Peacebuilding as Politics, Boulder: Lynne Rienner, 2001, pp. 1-20.

2 See the discussion in Antonio Donini, Norah Niland and Karin Wermester, eds., Nation-building Unraveled? Aid, Peace and Justice in Afghanistan, Bloomfield, CT: Kumarian Press, 2004, pp. 1-8.

3 Richard P. Cousens, "Providing Military Security in Peace-Maintenance", in Jarat Chopra, ed., The Politics of Peace Maintenance, Boulder: Lynne Rienner, 1998, p. 102 contributing states and in the multilateral arena, have waged fundamental contests over the determination of military mandates, specific military roles, training requirements, troop discipline, resource allocations, and multilateral command and control structures. What makes civil-military tensions more likely, and more harmful? First, tensions and rivalries differ systematically in relation to the particular civil and military actors in peacebuilding - in some measure a function of the division of roles among civil and military actors. Second, civil-military tensions are affected by the level/potential for violence in the post-conflict environment, particularly in relation to the coercive content of the external military's mission.

The first section of this article describes those military roles in peacebuilding, which make civil-military relations so vital to success. The second section discusses specific issues in military relations with three sets of civilians: command authorities, civilian agencies, and civilian populations. Military relationships with these three civilian groups arise in the context of the military footprint - the scope of military involvement in implementation. Military mandates that involve providing public security, disarmament and seizure of persons indicted for war crimes are more dangerous and imply larger military presence and intrusiveness in the wartorn society. The final section of this article illuminates trade-offs in policy decisions about the military footprint in peacebuilding.

\section{Military roles in peacebuilding}

The remark, attributed to former United Nations SecretaryGeneral Dag Hammarskjöld, that »peacekeeping is not a job for soldiers, but only soldiers can do it, « depicts the military role as a necessary evil. ${ }^{4}$ Soldiers might agree, particularly if peacekeeping breaks with their long-standing conceptions of military purpose. Although the rules have changed, there is at least one consistent norm in United Nations peacekeeping: the use of force to defeat a belligerent is prohibited. ${ }^{5}$ For

4 Quoted in Margaret Daly Hayes, »Political-Military Relations Within International Organizations «, report of the symposium at the InterAmerican Defense College, 28 September 1995, Fort McNair, Washington, D.C., 1995 , p. 7.

5 John Gerard Ruggie, »The UN and the Collective Use of Force: Whither or Whether? « in Michael Pugh, ed., The UN, Peace and Force, London: Frank Cass, 1997, p. 11. 
military forces, this means that in peacebuilding the center of gravity is commonly located in the civilian domain. Barred from war making, peacekeeping forces are all the more servants of civilian implementers engaged in peacebuilding.

Peacekeeping traditionally required impartial, lightly armed military personnel to monitor and observe the implementation of peace agreements between conflicting states. The military personnel who donned the blue berets of United Nations peacekeepers were generally from developed nations, but not major powers. As the Cold War ended in 1989-92, great powers got into the game, multilateral arrangements became more complex, missions became more coercive, and occurred within states.

Military arrangements became more diffuse. In Bosnia, great and major powers such as the United States, Britain, France and Germany acted through NATO and with UN preauthorization, and in Kosovo with UN post-facto legitimization. NATO Secretary-General Jaap de Hoop Scheffer has also mentioned the possibility of a peacekeeping role in the Israeli-Palestinian conflict. ${ }^{6}$ In Afghanistan and Iraq, the US formed its own coalitions and the UN wrestled with the challenges of coherence. Meanwhile, frustrated by great power reluctance to engage national or UN forces in Africa, West African nations have established their own missions under regional frameworks, including most recently a 2003 resolution by the African Union (AU) to approve the African Mission in Burundi. ${ }^{7}$ Similarly, Indonesia recently proposed the establishment of an Association of Southeast Asian Nations (ASEAN) Peacekeeping Force by $2012 .{ }^{8}$

The roles for external military personnel vary widely. Foreign military leaders sometimes participate in negotiating cease fires or even peace settlements of civil wars, as was done in Mozambique, Angola and Bosnia..$^{9}$ Military contributors perform or monitor military-oriented tasks such as demobilization, encampment and disarmament of parties. Enforcement of no-fly zones or cease-fires, for example, exercises external coercion. However, it might be sufficient to simply promote transparency among warring parties. In that event, external forces monitor cease-fires, disarmament, and demobilization. Securing relief convoys, as in Somalia, or ballot booths, as in Cambodia, requires passive coercion. External militaries might also play very non-coercive roles in support of civilian agencies, by lending craft to transport relief supplies, establishing camps for displaced people, and providing engineering and other expertise for reconstruction.

6 Jaap van Wesel, »NATO Chief Sees His Troops in West Bank and Gaza Peacekeeping Role«, The Jerusalem Report, 3 November 2003.

7 Africa Recovery, »Pan-Africa: Africa Builds Its Own Peace Forces «, Africa News, 23 October 2003. African peacekeeping was conducted under the framework of the Economic Community of West African States framework of the Economic Community of West African States
(ECOWAS) in Sierra Leone, Guinea-Bissau and Cote d'Ivoire; under the auspices of the Economic and Monetary Community of Central African States (CEMAC) in the Central African Republic; and the Southern African Development Community (SADC) in Lesotho and (rather more problematic) the Democratic Republic of the Congo. The Intergovernmental Authority on Development (IGAD) in East Africa was meanwhile engaged in mediation among factions in Sudan and Somalia.

8 »UN Terms ASEAN Peacekeeping Force Idea 'Very Exciting' «, Japan Economic Newswire, 24 February 2004

9 Anthony D. Marley, »Responsibilities of a Military Negotiator During Peace Talks«, Parameters, Summer 1996, pp. 67- 78.
Given expanded roles in modern peacekeeping, military contributors can expect to deal with more complexity in their relationships. Multiple levels of civilian authority, active civilian management of peace processes, large numbers of civilian agencies active in theater, and scrutiny over compliance with norms of civilian protection increase the number and character of relationships. In short, this use of force makes for interesting and controversial civil-military relations.

\section{Civil-military relationships}

Civilian control of military force and military control of operations are fundamental issues in civil-military relations. Numerous sub-issues arise during attempts to improve civilian control and military effectiveness, including military professionalism, separation of military and civilian spheres, determination of roles and missions, contests over resources, and the mobilization of interest groups. These issues, long recognized as significant in domestic civil-military relations, also play out in the international context of peace implementation.

When discussing civil-military relations in international peacebuilding, it is critical to ask which civil-military relations one is considering. As the following table shows, these issues are relevant in military relations with different sets of civilians. In addition to command relationships, two other sets of civil-military relations are at play in peacebuilding: external military relations with civilian agencies and their relations with civilian populations.

\subsection{Civil-military issues by categories of civilians}

\begin{tabular}{|l|l|l|l|}
\hline $\begin{array}{l}\text { Category of } \\
\text { Civilian: }\end{array}$ & $\begin{array}{l}\text { Political Leader- } \\
\text { ship }\end{array}$ & $\begin{array}{l}\text { Participating Ci- } \\
\text { vilian Agencies }\end{array}$ & $\begin{array}{l}\text { Civilian Popula- } \\
\text { tion }\end{array}$ \\
\hline $\begin{array}{l}\text { Nature of } \\
\text { Relation- } \\
\text { ship: }\end{array}$ & Authoritative & Coordinative & Subordinate \\
\hline $\begin{array}{l}\text { Primary } \\
\text { Level of } \\
\text { Analysis: }\end{array}$ & Strategic & Operational & Tactical \\
\hline $\begin{array}{l}\text { Potential } \\
\text { Civil- } \\
\text { military Is- } \\
\text { sues: }\end{array}$ & $\begin{array}{l}\text { Civilian control } \\
\text { - or institutional } \\
\text { equilibrium in } \\
\text { calling the shots } \\
\text { or getting in- } \\
\text { volved }\end{array}$ & $\begin{array}{l}\text { Cultural differ- } \\
\text { ences - or ability } \\
\text { to get along } \\
\text { with civilian } \\
\text { agencies }\end{array}$ & $\begin{array}{l}\text { Military profes- } \\
\text { sionalism - or } \\
\text { good conduct }\end{array}$ \\
\hline
\end{tabular}

\subsection{Relations with civilian command authorities}

Military relations with their command authorities are intentionally hierarchical. Domestic civil-military relations are significant, even in multinational missions, which have two tiers of authority. Command, as generally understood, includes not simply authority over personnel matters like 
promotions, but also the ability to change missions. ${ }^{10} \mathrm{Na}-$ tional governments retain command authority over military forces, even if operational authority is transferred, for example, to the United Nations.

The UN does not have the ability to exercise full command. The United Nations term »operational authority« is to a certain degree a combination of the elements of NATO's operational command and operational control:

»United Nations operational authority entails the exclusive authority to issue operational directives within the limits of 1) a specific mandate of the Security Council, 2) a specific geographic area (the mission area as a whole), and 3) an agreed period of time. Operational authority includes the authority to assign separate tasks to sub-units of a contingent and general responsibility for logistic support. «11

The degree of operational authority granted to the UN by troop contributing states is a political decision to be determined by the national authorities.

Political control, if not civilian control, is needed to commit troops to peacekeeping. However, although peacebuilding generally promotes the norm of civilian control, in the past Nigerian peacekeepers were not, and today Pakistani peacekeepers are not, governed by civilians. Moreover, today's United Nations peacekeeping missions are manned primarily by developing nations. ${ }^{12}$ Militaries that acquire muchneeded funding, training, and equipment from participation in UN peacekeeping, would seem less likely to balk at deployments than wealthier armed forces that see peacekeeping as »auxiliary.«

It is no coincidence that United States military leaders, who generally do not see peacebuilding as a primary mission, have challenged civilian leadership before and during missions. American civilian and military leaders were bitterly divided over the Bosnia strategy. Diplomat Richard Holbrooke, who negotiated a peace accord for the warring Bosnian factions at Dayton, Ohio, and Leighton Smith, the military man implementing the agreement, argued with each other publicly, including public complaints by Holbrooke about the poor quality of military advice. ${ }^{13}$ The level of civilian expertise and the role of military advice affect the authoritative relationship of civilian command over soldiers in peace operations.

A more challenging issue of command and control arises from the nature of the use of force in peacebuilding. In war,

10 To add to the confusion, NATO doctrine, for example, distinguishes between operational control and operational command. See Joint Publication 1-02, »DOD Dictionary of Military and Associated Terms. As amended through 09 January 2003.« Available online at http://www.dtic. $\mathrm{mil} /$ doctrine/jel/doddict/natoterm/o/

11 United Nations, Department of Peacekeeping Operations, General Guidelines for Peace-keeping Operations, UN/210/TC/GG95, New York, October 1995 , p. 36

12 In February 2004 the top ten ranking contributors were Pakistan, Bangladesh (over 6,000 troops), Nigeria (more than 3,500), India, Nepal, and Ghana (over 2,000), Uruguay, Jordan, Kenya and South Africa (over 1,400). United Nations Department of Peacekeeping Operations, "Monthly Summary of Military and Civilian Police Contributions to UN Operations«, 29 February 2004. Available online at http://www.un.org/ Depts/dpko/contributors/index.htm.

13 Michael Kirk and Rick Young (producers and writers), Peter J. Boyer (correspondent), »Give War a Chance, «Frontline Program \#1715. Aired on PBS 11 May 1999. Holbrooke was also doubtful that the US military would make a sincere effort to capture indicted war criminals in Bosnia. military commanders tend to prefer freedom of action, or operational control. ${ }^{14}$ Peace operations lend themselves to civilian micro-management of the use of force. One attempted solution is to distinguish carefully between civilian and military mandates. US military leaders lobbied for and got a firewall between military and civilian tasks into the Dayton Accord for Bosnia. Thanks to this compartmentalization, some perversely portray the implementation of the Dayton Accord as a military success and civilian failure. ${ }^{15}$

Multilateral operations add complexity. NATO itself was divided over Bosnia during the UNPROFOR era. European nations, with large numbers of troops on the ground under UNPROFOR, were wary of the American Congress's proposal to lift an arms embargo against the Bosnian Muslims (or Bosniaks), and to strike at Serbia - dubbed »lift and strike.« Furthermore, the two major intergovernmental organizations (IGOs) engaged, the UN and NATO, were »deeply and publicly at odds « over the proper military response to the situation in Bosnia in $1994 .{ }^{16} \mathrm{~A}$ »dual key « arrangement provided for UN approval of military action by NATO. This command system was an issue during a May 1995 crisis in which the UN Bosnia Force Commander, British General Rupert Smith, called for air strikes against the Serbs, who were shelling civilians in designated "safe areas." The request went all the way to the Secretary-General, who turned it down. From a military perspective, the command arrangements were not only untidy, they were unsafe. Not surprisingly, the dual key arrangement was changed in July, in the wake of the massacre of an estimated 7,414 Muslims at Srebrenica. ${ }^{17}$ Interestingly, after this change, the »keys « for air strike launch were held by all military men: General Bernard Janvier, overall commander of UN forces (rather than with the UN Special Representative Yasushi Akashi), and Admiral Leighton Smith, NATO's Southern Region commander. External involvement afterward entered a new phase marked by the creation of a larger force and authorization of massive air attacks.

The commander of the Kosovo Force (KFOR) complained that he had $»$ nothing to command. ${ }^{18}$ Many of his proposals to military leaders of the national military contingents were referred back to governments for approval. Major power

14 Max Manwaring takes the notion from Clausewitz that the goal of policy is the »[d]estruction of an opponent's military forces or the means for waging war ", to mean that "it is the military that dominates to create conditions that other means could not make. "Max G. Manwaring, "Limited War and Conflict Control "in Stephen J. Cimbala and Keith A. Dunn, eds., Conflict Termination and Military Strategy: Coercion, Persuasion, and War, Boulder and London: Westview Press, 1987, p. 60. Italics added.

15 George A. Joulwan and Christopher C. Shoemaker, Civilian-Military Cooperation in the Prevention of Deadly Conflict: Implementing Agreements in Bosnia and Beyond, New York: Carnegie Corporation, December 1998. The authors commend the US military mission in Rwanda as a success, although the US military did not intervene to stop the genocide, because US commanders avoided »mission creep $«$.

16 William H. Lewis and Edward Marks, »Searching for Partners: Regional Organizations and Peace Operations«, McNair Paper 58, Washington, DC: INSS-NDU, June 1998.

17 William Shawcross, Deliver Us From Evil, New York: Simon and Schuster, 2000, pp. 146-192.

18 Independent International Commission on Kosovo, Kosovo Report, New York: Oxford University Press, 2000, p. 107. See also James Fergusson, $A$ Mile Wide and an Inch Deep: Multilateralism and the Command and Control of Multinational Military Forces in Peace Operations. York University Centre for International and Security Studies Working Paper No. 8, June 1998, p. 2 . 
militaries, as in Bosnia and Somalia for example, generally took orders from their own governments.

Meanwhile, national preferences also translate into lobbying for appointments of military leaders to international peacekeeping missions. France lobbied for a French force commander of UNPROFOR in Bosnia in 1993, and the Swedish commander was changed for a French general. Undiplomatically, the French defense minister announced the change on French television before UN Secretary-General Boutros Boutros-Ghali notified the Swedish government. ${ }^{19}$

Coalitions require consent and compromise, principles that seemingly conflict with requirements for military effectiveness. ${ }^{20}$ Lt. General Michael Short, the American who directed the NATO bombing campaign during the 78-day war against Serbia over Kosovo, alleged that coalition politics caused strategy to suffer and pilots to be at risk. The American contribution to the air campaign was by far the largest, but the decision-making was multinational and even micromanagerial: »Targeting was a problem to us, « Short said, »... and as you know, the red card was played by France in particular [to veto selected targets]. "1 $^{21}$

In sum, coercive peacekeeping stresses the relationship between military leaders and civilian masters. Just when a mandate permits the use of force, national governments are more likely to put limits on its use in support of policy goals, watering down strategies to a lowest common denominator. Just when military might is most needed to create peace, missions are hampered by convoluted command and control structures, national troop withdrawals, or reluctance by political or military leaders to commit to operations in the first place.

\subsection{Cooperative relations with civilian partners}

»Unity of command « is vital to operational effectiveness in war. The analogous concept in peace operations, »unity of effort « (or »coherence «) with civilian agencies, is also intended to achieve desired outcomes more quickly. This notion of unity implies shared civil-military objectives; however, civilian and military agendas may differ.

Expanded civilian non-governmental and intergovernmental participation in peace processes after World War II created a new set of civil-military considerations at the operational level. In contrast to previous history, civilian agencies are typically on the scene before the military arrives.

International military forces and civilian humanitarian organizations have been depicted as »two natural partners, who had long been intended for one another but had never

19 William Shawcross, Deliver Us From Evil, New York: Simon and Schuster, 2000, p. 112

20 Nora Bensahel, »The Coalition Paradox: The Politics of Military Cooperation«, Ph.D. Dissertation Stanford University, August 1999, p. 29.

21 Lt. Gen. Michael Short to the US Senate Armed Services Committee, quoted in BBC News, »US General Condemns French 'Red Card'«, 22 October 1999. Available online at http://news.bbc.co.uk/1/hi/world/ 482015.stm. See also »Interview with Lt. Gen. Michael Short, «PBS Frontline, War in Europe PBS Online, and WGBH/Frontline Site, produced February 2000. Available online: http://www.pbs.org/wgbh/pages/frontline/ shows/kosovo/interviews/short.html. actually met during the Cold War.«22 However, the relationship might be better described as a »marriage of convenience. ${ }^{23}$ NGOs and IGOs operating in a hostile environment need the military for security and logistics, and military forces need these civilians to take over humanitarian relief and enable them to leave. The participants often enter with incompatible expectations and in part acrimoniously.

Cultural differences between hierarchical military forces and decentralized non-governmental organizations (NGOs) abound. During the United Nations Angola Verification Mission (UNAVEM), lack of professional respect between peacekeepers and humanitarian workers hampered demining and demobilization efforts. ${ }^{24}$ Time horizons differ. Civilian actors tend to operate for longer periods in the field, so that civil-military relationships are recreated to some extent with each rotation. While many civilian agencies look at long-term development needs for war-torn societies, military personnel are more likely to focus on achieving their objectives in a specific mission.

NGOs are non-governmental, but not necessarily neutral, actors. Those that focus on human rights monitoring and advocacy are »far from neutral, « says Pamela Aall, adopting »principled and often adversarial positions with regard to both official institutions and the parties engaged in a conflict. $\ll^{25}$ On the other hand, relief, economic development or conflict resolution organizations tend to be impartial, sometimes more so than military forces.

Coercive interventions force aid organizations to make difficult choices between seeking the protection of peacekeeping forces and maintaining distance from them, thereby giving the impression of impartiality. In Somalia in 1992, prior to the arrival of the US-led United Task Force (UNITAF), some relief agencies hired protection from armed locals. ${ }^{26}$ This created difficulties when UNITAF sought to demilitarize the environment. Ten years later, civil-military relations were worse in Afghanistan. NGOs protested against United States military actions, which concurrently delivered aid and bombs. Sally Austin of CARE International complained about American Special Forces: »They are here in civilian clothes, saying they are doing humanitarian work. But they are putting our own efforts as humanitarians at risk. ${ }^{27}$

22 Hugo Slim, »The Stretcher and the Drum: Civil-Military Relations in Peace Support Operations, «International Peacekeeping, Vol. 3, No. 4, 1997, p. 129

23 Andrew S. Natsios, "NGOs and the UN System in Complex Humanitarian Emergencies: Conflict or Cooperation? « in Thomas G. Weiss and Leon Gordenker, eds., NGOs, the UN, and Global Governance, Boulder and London: Lynne Rienner, 1996, p. 81.

24 Nicole Ball and Kathleen Campbell, Complex Crisis and Peace: Humanitarian Coordination in Angola, prepared for the United Nations Office of Humanitarian Affairs (OCHA), New York: United Nations, March 1998, pp. manitari.

25 Pamela R. Aall, "NGOs and Conflict Management, «Peaceworks, No. 5, Washington, DC: United States Institute of Peace, February 1996, p. 5.

26 Charles Rogers, »The Changing Shape of Security for NGO Field Workers«, Together Magazine, No. 57, January-March 1998, available via WorldVision's website: http://www.worldvision.org/worldvision/pr.nsf/ stable/NGOsecuritya. Former US Ambassador to Somalia, Robert Oakley, discusses the problem in »An Envoy's Perspective«, Joint Forces Quarterly, Autumn 1993, pp. 44-55.

27 Susan Glasser, "Soldiers in Civilian Clothing; U.S. Forces' Humanitarian Effort in Afghanistan Draws Ire of Aid Agencies", Washington Post, March 28, 2002, p. A20. 
Finally, the UN Office for the Coordination of Humanitarian Affairs (OCHA) confronted the reality of belligerency in the US- and British-led invasion of Iraq in 2003. OCHA's »General Guidance for Interaction between United Nations Personnel and Military Actors in the Context of the Crisis in Iraq « emphasized operational independence of UN personnel and regarded coalition forces as belligerent occupants. ${ }^{28}$ This was an astonishing break with the trend toward a more integrated approach to post-conflict security-building. After decades of humanitarian intervention, belligerents and humanitarian actors were clearly identified.

\subsection{Relations with civilian populations}

When missions are coercive, military interactions with civilian populations are also more intense. This was obvious in Cambodia, where the large external military presence had a tremendous impact on the economy and social life. ${ }^{29}$ This is more obvious still in Iraq today, where the environment has been too unstable for a United Nations mission to be considered. The coalition that waged war in 2003 struggled in 2004 to stabilize an environment in which the Red Cross and the UN itself have been attacked. »Everyone's a target now, « said a security consultant in Baghdad in April 2004, »They won't stop and ask if you work for an NGO...the CPA, or a security company...It's a guerrilla war. They don't care who they get. ${ }^{30}$

The requirements of peacekeeping are sometimes compared to those of counterinsurgency operations in which the civilian population is the center of gravity of military operations. In internal conflicts, leaders of factions depend on their relations with the population for their ability to defend or attack, and without whom they could not maintain their position, sustain access to spoils of war, and avoid prosecutions, such as for war crimes. ${ }^{31}$ The relationship between external military forces and the civilian population is a significant strategic consideration.

Military professionalism is vital when troops operate in heavily populated environments. Unfortunately, some troops are more professional than others. The commission of crimes by peacekeepers themselves can undermine public support for the mission. The types of misconduct alleged to have been committed by multinational peacekeeping troops include torture, rape, murder, black marketeering, racketeering, and child prostitution. ${ }^{32}$ Some Bulgarian troops stationed with UNTAC in Cambodia were characterized as, $»$ more interested in organizing prostitution rings than in

28 UN Office for the Coordination of Humanitarian Affairs, „General Guidance for Interaction between United Nations Personnel and Military Actors in the Context of the Crisis in Iraq, « 21 March 2003. Available online tors in the Context of the Crisis in Iraq,
via ReliefWeb: http://www.reliefweb.int.

29 When attacking UNTAC forces, the Khmer Rouge claimed to be protecting women and children from an occupation army.

30 Bay Fang, Kevin Whitelaw and Ilana Ozernoy, »Hell's Fury, « US News and World Report, Vol. 135, No. 12, 12 April 2004, p. 16.

31 Pär Eriksson, »Civil-Military Co-ordination in Peace Support Operations An Impossible Necessity? « The Journal of Humanitarian Assistance, posted 16 September 2000 on http://www.jha.ac/articles/a061.htm.

32 »Keeping the Peace? « Dateline NBC. Program aired 10 January 1999. Lea Thompson reporting, Mark Feldstien producing. UN officials interviewed for this program conceded that the DPKO has not kept statistics on crimes committed by its peacekeeping troops. monitoring cease-fire violations. «33 Peacekeepers have been implicated as patrons in the industry of sex slavery in the Balkans. In 2002, the Head of the UN Office for Human Rights in Bosnia, Madeleine Rees, said, »[t]here is absolutely no dispute that the sex traffic market [in the Balkans] came with the arrival of the peacekeepers. $\ll^{34}$

Civilian police officers are generally preferred for civil order tasks, precisely because they have more experience operating in civilian environments. ${ }^{35}$ Ironically, the focus of investigations into allegations of patronizing and even participating in the Balkans sex trade is on civilian police. A senior official conceded that military peacekeepers are generally easier to discipline than civilian participants, as military organizations train and rigorously police their own members.

Some militaries, particularly NATO members and the armed forces of wealthier nations, receive better training than others. The behavior of American troops therefore ought to be exemplary. Even so, a US Army investigation into the abuse of Kosovar Albanian civilians by a US Army Unit on peacekeeping duty identified a lack of proper training for missions that required soldiers to temper »their combat mentality. ${ }^{36}$

High quality training and standards for conduct are clearly needed, with emphasis on military professionalism and discipline. ${ }^{37}$ The UN Department of Peacekeeping Operations (DPKO) has reacted to shortcomings in training with the creation of the Training and Evaluation Service (TES), which develops and provides standardized peacekeeping training guidance.

International organizations such as the UN do not have the same leverage over misbehaving peacekeepers as do civilian officials at home, since soldiers are generally immune from prosecution except by their own governments. ${ }^{38}$ Problems in the field can lead to civil-military tensions back home. A cover-up at the senior officer level during the inquiry into the murder of a Somali youth in 1993 by Canadian peacekeepers provoked a civil-military relations crisis in Canada

33 William Shawcross, Deliver Us From Evil, New York: Simon and Schuster, 2000, p. 80

34 It is estimated that in 2000 the sex trade involved 200,000 southeastern European women - and an increasing number in the age group of 15-18. "Sins of the Peacekeepers, « Sunday Herald (London) 30 June 2002, http://www.sundayherald.com. See also Barbara Crossette, "Peacekeeping's Unsavory Side, «UN Wire, 11 June 2003.

35 Kathryn Bolkovac, a human rights investigator, has sued DynCorp in London, the contractor for United Nations Civilian Police, charging unfair dismissal after she sent e-mail messages to the UN Mission about UN police officers and humanitarian workers exploiting women forced into prostitution. Steward Payne, »Teenagers 'used for sex by UN in Bosnia,'« The Daily Telegraph (London), 25 April 2002, p. 17.

36 Associated Press, »US Kosovo Report Shows Misconduct, «The New York Times, 18 September 2000, Available online at http://www.nytimes.com.

37 Thomas S. Szayna, Preston Niblack and William O'Malley, »Assessing Armed Forces Deficiencies for Peace Operations: A Methodology, «International Peacekeeping, Vol. 3, No. 3, Autumn 1996, pp. 77-91. The Brahimi Panel in August 2000 notes that, although member states are primarily responsible for peacekeeping training, the United Nations ought to provide guidelines and performance standards. See the Brahimi Panel's Report A/55/305-S/2000/809, 21 August 2000, General Assembly Resolutions $46 / 48,48 / 42,49 / 37$, and the Secretary-General's Report A/55/502, 20 October 2000 .

38 An Italian commission conducted an inquiry that exonerated two Italian generals who resigned over the scandal in June 1997. »Italian Army Cleared of Widespread Abuse in Somalia«, CNN World News, 9 August 1997. URL: http://cnn.com/WORLD/9708/09/italy.somalia.index.html. 
as an entire regiment was dissolved. ${ }^{39}$ The International Criminal Court is a forum for prosecution of alleged crimes during missions that have to date been confined to national military tribunals. This very issue is part of the US rationale for refusing to participate in the court.

\section{Trade-offs in intervention strategy}

Intervention strategies include choices about the relative weight - in roles, resources and composition - of civilian and military components of the peace mission. These choices affect civil-military relationships. In observer or traditional peacekeeping missions during the Cold War, often involving fewer than 1,000 troops, there was no basis for military components to challenge, and little opportunity for them to thwart, the dominance of diplomatic components. Coercive strategies require more military forces. These commitments involve more risk, more expense, and more likely civilian micromanagement of military operations. In sum, coercive strategies exacerbate tensions in each of the civil-military relationship sets.

In multinational missions, coercive actions are more problematic because of variations in doctrinal approaches to peacekeeping. The approach of United States civil-military operations (CMO) doctrine, incorporating principles of war, for example, contrasts markedly with the emphasis in other civil-military cooperation or CIMIC doctrines.

General agreement on the principles of traditional UN peacekeeping does not translate to agreement in modern peace enforcement. The United Nations Secretariat offers guidelines rather than doctrine as such. Of the various regional organizations, NATO has made more progress than most toward a comprehensive CIMIC doctrine, although the Economic Community of West African States (ECOWAS) and others are actively engaged in capturing the lessons of their peacekeeping experiences. ${ }^{40}$ NATO CIMIC doctrine acknowledges the possibility of coercive intervention, while respecting the requirements of coordination and cooperation of civil and military actors in support of the mission.

Just as we must ask which civilians form the civil-military relationship, it also matters which military forces are involved. Some militaries bring international political baggage. Accepting troop contributors from interested regional actors or major powers may increase the odds of military effectiveness at the expense of political impartiality. Secondly, militaries have different orientations toward society. Some have been segregated from society and oriented toward defense against uniformed adversaries on a defined battlefield, as was the US

39 See the five volumes by the Canadian Commission of Inquiry into the Deployment of Canadian Forces to Somalia, Dishonoured Legacy: The Lessons of the Somalia Affair, Toronto: Canadian Government Publishing, 1997.

40 The Challenges Project, Challenges of Peace Operations: Into the 21st Century - Concluding Report 1970-2002, Stockholm, Sweden: Elanders Gotab. 2002 pp. 89-109. Also available online at http://www peacebuil dingchallenges.net. See also Mark Malan, »Towards an Integrated Doctrine for Peace Support Operations in Africa«; Monograph 46, Building
Stability in Africa: Challenges for the New Millennium, February 2000, availStability in Africa: Challenges for the New Millennium, February 2000, avail-
able online at http://www.iss.co.za/Pubs/Monographs/No46/Towards.html. military during the Cold War. Other militaries have more recent and extensive experience with counter insurgencies or other internal control functions.

When member states consider participation in a peacekeeping mission, two criteria for that participation are national interest and estimations of likely success. Canadian General Romeo Dallaire, whose life changed forever ten years ago when, as UN Force Commander, he was unable to stop the Rwandan genocide, regrets the role of national interest. »Who do I blame? « he asks, »I blame the lack of statesmanship. I blame the Americans - leadership, which includes the pentagon in projecting itself as world policeman one day and recluse the next... President Clinton saying...that the Americans will go in only if it's in their selfinterest. «1 External national motivation to contribute troops to peace implementation brings disadvantages as well as advantages. National interest ensures a sense of purpose and support from the public at home. UN missions have been generally successful at containing conflict, even if they have fared poorly overall at resolving it. ${ }^{42}$ However, this evidence suggests that UN missions are really an extension of great power management. When national interest is obvious, humanitarian operations may appear as rehearsals for armies of the developed countries to rapidly project power into the developing world. ${ }^{43}$ Meanwhile, UN military forces seek to be perceived as impartial in the field.

Estimations of success provide further criteria, based on power balances among belligerents, the quality of a settlement, and indigenous resources for reconstruction. An approach that picks implementation based on its likely success minimizes the risk that failures in peace implementation will erode its legitimacy and the morale of multilateral participants. As a disadvantage, this approach may cause the international community to abandon some of the peoples that are in greatest need of assistance, and leave them to their own devices as human rights abuses, genocide, and the ravages of war continue.

Choices about organizational structures - how multilateral and how military - were controversial in the recent occupation of Iraq. Nationalization of peace implementation, as defined by an emphasis on the leadership of contributing states, helps to overcome the reluctance of its soldiers to serve under foreign officials and streamlines policy channels compared to highly complex multilateral operations. On the other hand, choosing multilateralization potentially pools resources and provides a better sense of impartiality that may be necessary to the maintenance of consent of the parties to the conflict. The civil-military mix itself also matters. The use of military forces for peace implementation accus-

41 Romeo Dallaire interview with Peter Mansbridge, The National Canadian Broadcasting Corporation, 24 October 2003.

42 Duane Bratt, "Assessing the Success of UN Peacekeeping Operations «, in Michael Pugh, ed., The UN, Peace and Force, London: Frank Cass, 1997, pp. 64-81.

43 N. Stockton, "An NGO Perspective on Civil Reconstruction «, paper presented at the Refugee Studies Programme Conference on the Role of the Military in Humanitarian Emergencies, Oxford University, October 1995, cited in Hugo Slim, »The Stretcher and the Drum: Civil-Military Relations in Peace Support Operations«; International Peacekeeping, Vol. 3, No. 4, 1997, pp. 123-140. 
toms transitional societies to military operations in the civil realm, and thus undermines the process of democratization. ${ }^{44}$ Alternatively, external military forces might spread the norms of good civil-military relations if they are aware of the weight of their example and know how to conduct themselves appropriately. ${ }^{45}$ This article has shown the emerging context in which that assumption plays out, and some of the challenges to such leadership by example.

\section{Conclusion}

When we distinguish among types of missions and identify the types of civil-military relationships that are relevant in

44 For the argument that external military involvement increases military operations of local armies and undermines democratization, see Joy Olson and Preston Pentony, US Military Humanitarian and Civil Assistance Programs and Their Application in Central America, Albuquerque, New Mexico: Interhemispheric Resource Center, 1995

45 The latter view has been an underlying assumption in United States civic action programs. See various chapters in John W. de Pauw and George A. Luz, eds., Winning the Peace: The Strategic Implications of Military Civic Action, New York: Praeger, 1992. peacebuilding, it is clear that the character of the mission and the mix of civil-military organizational components require better conception in both planning and execution. Command and control arrangements of multilateral peacebuilding forces are significant to both civil-military relations and the prospects of peace. However, more nuanced division of labor issues arise. The division of labor among civilian and military institutions of contributing states must be resolved by interagency agreement and the determination of a »lead agency." The division of labor between civilian and military institutions at the international level involves not only determining roles of multilateral militaries, but also those of civilians of international and non-governmental organizations. Finally, societies attempting to rebuild after war will be making their own decisions about the division of labor between civilian and military institutions as they transform their own security sector. It is imperative that, as external implementers seek to provide war-torn societies space to make such transformations, they do so with care to the example they set in the process.

\title{
The civil-military interface with local populations: Impact on peacebuilding strategies
}

\author{
Ann M. Fitz-Gerald*
}

\begin{abstract}
Multinational troops are increasingly deployed to internal wars characterized by multiethnic violence, paramilitary regimes and autocratic state leadership. Their closeness to the local populations presents interesting implications for contemporary peacekeeping training programs and the further development of military doctrine in warfighting, peace enforcement and peacekeeping environments. In most cases, regional paramilitary forces and warlords garner local support by convincing indigenous populations that their allegiance will be rewarded with the provision of individual security and protection. The success of the multinational forces in redirecting this allegiance depends largely on how the force is perceived as a credible security provider. For this reason, a careful balance must be preserved between maintaining a »robust posture« and interfacing within the local population to strengthen confidence-building measures.
\end{abstract}

Key Words: peacekeeping, peacebuilding, peace enforcement, multinational military interventions, coalition forces, military culture

$\mathrm{M}$ ilitary intervention through multinational peace support operations has become increasingly challenging due to the complex environments and the many different players that are brought into theatre. Whereas the prevailing model represents a major departure from the former »buffer-zone« peacekeeping, where warring factions were separated by a demarcation zone, nowadays it

\footnotetext{
* Ann Fitz-Gerald is an Associate Professor in the Department of Defence Management and Security Analysis at Cranfield University, UK. She worked in the Canadian Liaison Office at NATO Headquarters in Brussels, Belgium, and has field experience in Angola, Sudan, Sierra Leone, all Former Yugoslav Republics and Colombia, among others.

This article was prepared for the United Nations University-IFSH project »The Role of the Military in Post-Conflict Peacebuilding. "The author ac"The Role of the Military in Post-Conflict Peacebuilding." The author ac-
knowledges the project directors Hans-Georg Ehrhart (IFSH) and Albrecht Schnabel (swisspeace), the members of the project team as well as two anonymous peer reviewers for their input in the preparation of this article.
}

is quite commonplace for indigenous populations to live in close proximity of the intervening military forces and, as such, are able to view their behavioral conduct and operational effectiveness. A common method used by warlords, nonstate actors and paramilitary regimes in garnering the support of local communities, is to offer security guarantees in exchange for their support. As a result, the main task for the international community in responding to these conflicts involves determining the basis for local support and seeking to redirect the population's allegiance towards the interventionist forces by demonstrating the provision of credible security. This is all the more important as research indicates that disparate national approaches observed in recent multinational peace support operations have had a di- 